\title{
RURAL YOUTH BEHAVIOR IN WATCHING TELEVISION (Case Study Rural Youth in Ciasmara Village Pamijahan Sub-District, Bogor Regency)
}

\author{
Yogaprasta Adi Nugraha ${ }^{\text {a) }}$, David Rizar Nugroho ${ }^{\text {a) }}$

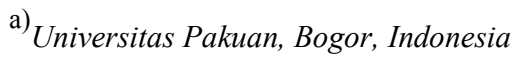 \\ Corresponding Author: yogaprasta_adinugraha@yahoo.com
}

Article history: received 17 January 2019; revised 27 January 2019; accepted 01 February 2019

\begin{abstract}
Family is an important social unit that forming youth identity, but in the other hand family is also a place where contestation happened. Power-relation inside family is commonly happened during several activities such as watching television, having dinner, and prior go to school. The objective of this research is to unmasking the reality of power relation in television watching activities. Qualitative method is used to dissect this phenomenon. In the context of families that only have one television, power relation in watching television is inevitable, especially the prime time, because at this time all family members watch television. This study found that there are several actors who hold important role in power relation, such as Little brother, Grandma, and Father. Their domination have made rural youth become marginalized on their own house
\end{abstract}

Keywords: Power Relation, rural youth, rural family, space contestation

\section{INTRODUCTION}

Family is a group of people who live together in a shared residence and each member feels the inner connection so happens to affect each other and care for each other. Family is defined as two or more people who are connected with blood relations, marriage or adoption (law) who have a place to live together. Galvin and Brommel in Tubbs and Moss [1] state that families are a network of people who share their lives for a long time, who are bound by marriage, blood or commitment, legal or not, who consider themselves as family and who share future expectations of relationships.

Watching TV is a time spent activities, critically in unmasking the activities of watching TV we will see the existence of contestasion between the parties in family. Unlike TV watching in urban areas, where each family tends to have more than one unit of TV, the tendency to friction in meeting information needs tends to be small, while in the family village only has one unit TV. Space contestasion between family members in watching television can be seen in the context of power relations. Power relations that occur in the search for information can be seen through gender perspective so that in the end it will be seen who tends to master information in the family.

The researah related to rural-youth in utilizing media had been discussed before by Nugraha [2]; Nugraha and Herwati [3]; Vadiani [4]; Winangun and Nugraha, [5]. All the research showed that rural-youth have utilized media most of it are TV and Internet. Meanwhile the study about how media contributed to rural-family economic had been discussed by Nugraha and Siregar [6]; and Nugroho [7].
Based on the problem above, this research will answer some research questions, namely:

1. How is the behavior of rural - youth in watching TV?

2. What is the power relation that occurs in watching television?

This study generally aims to see how far power relations occur in watching television activities in the family. But in more detail, this research aims to:

1. Describing rural - youth activity in watching TV.

2. Assessing power relations and space contestation that occur in watching televisin.

This research is expected to provide benefits to:

1. The government, contribute to the idea that the high activity of young people outside the village is due to the spatial struggle in the family sphere.

2. In the perspective of communication, contribute to the idea that communication development will not run optimally without accompanied by communication at the level of the micro level.

Family

The family is the first and foremost place for its members to develop potential, develop social and economic aspects, and build affection between family members. The definition of the family used as a socioeconomic unit within the society which is the basis of all societies that are the foundation of all societies, is a group of two or more people who have interpersonal interaction networks, relationships, marriage relationships, adoption (Puspitawati [8]). Parenting is a habit that is usually done by fathers and mothers applied to children in its development, various forms of 
parenting can be applied to children, but it is very wise if the parenting style to be given to children is adjusted to the age and ability of children [9]

According Soelaeman in Puspitawati [8] family is a group of people who live together in a place to live together and each member feel the inner connection so happens mutual influence and mutual attention. Based on the above description, it can be concluded that the definition of the intensity of family communication is the level / size of how often communication / interaction occurs between parents with children in order to give the impression, desire, attitude, opinions and understanding, based on love, same, appreciation, honesty, trust and openness among them. Traditionally, families are defined as two or more persons associated with blood relation, marriage or adoption (law) that have shared residence. Galvin and Brommel in Tubbs and Moss [1] state that the family is a network of people who share their lives for long periods of time, married, committed or committed, married or not, who consider themselves to be families and who share future expectations of relationships. Parents and children are networks that are bound by blood relationships

\section{Socialization by Media}

Meanwhile, in modern society, communication is a very important requirement, especially to receive and convey information from one party to another party. Due to the rapid development of technology, information about events, short messages, news, science, etc. Can be easily accepted by the public so that mass media have an important role in the process of transforming values new to the community (Narwoko and Suyanto [10]). The mass media is a powerful media of socialization in shaping new beliefs or maintaining new beliefs. Even the process of socialization through mass media scope more broadly than other socialization media.

\section{RESEARCH METHODS}

This research was designed using descriptive qualitative approach to reveal reality about power relation in information search activity on television. Descriptive qualitative research is done by developing concepts and collecting data, but not testing hypotheses (Singarimbun and Effendi [11]).

Case study was used as research method, which is conduct detailed research about a person (individual) or a social unit for a certain period of time. This case study method has its own uniqueness or superiority in the social research. The Case Study provides researchers with extensive access or opportunities for in-depth, detailed, intensive, and comprehensive review of the social unit under study. Case studies can also enter the smallest social units such as associations, groups and other forms of social units.

Ciasmara village, Pamijahan Subdistric was chosen purposively. Ciasmara is a one of rice production village in Bogor Regency, Ciasmara village is still categorized as agriculture village, moreover, strong religious tradition and also have characteristic of village which is located between rural and urban and it is also supported by TV and Telecommunication network.

The study has been done from January 2018 to May 20118. The research stages were divided into 5 main stages: (1) preparing research proposal, (2) literature study, (3) down field, (4) compilation of result research (5) final report writing.

This study used qualitative approach. Qualitative approach does not use the term population but rather leads to social situations consisting of the context of place, actors, and activities. Based on these three contexts, the subjects in this study are families in the villages that use TV (the perpetrator), Ciasmara Village in Pamijahan Subdistrict (place), and power relations and space contestation in family (activity)

Research subjects in qualitative research are not called respondents but as key informant. Informants in qualitative research is not called statistical samples that represent the population for purposes of generalization of the population but it is selected based on the considerations and research objectives of developing concepts and theories (Sugiyono, [12]). The determination of informants was conducted intentionally with consideration of the parties substantially related to this research plan, such as parent (father and mother), youth, (subject and object of television viewing behavior).

Observations will be used to determine how the power relations in the family. Meanwhile, in-depth interviews are used to obtain related information: (1) power relations in the family, (2) family behavior in using mass media especially television, and (3) parents and youth views on power relations in information search on television. Focus Group Discussion (FGD) was conducted to confirm the findings found from indepth interviews and observations.

Data analysis has been done in parallel during the research activity. Data analysis has been done since the data collection until the writing of final report. Stages of data analysis include:

1. Data reduction, which summarizes and selects main points, focuses on matters directly related to the analysis of studies, searching for themes and patterns. Through data reduction is expected to provide a clear picture and make it easier for researchers to perform further data collection and seek additional data if needed.

2. Data Presentation, which presents data in various forms such as conversation, narration, descriptive 
social situations. Research data are presented in the form of narrations, which is equipped with quotesquotations from resource persons and photographs.

3. Interpretation of data, which provides interpretation of data obtained during research activities

\section{RESULTS AND DISCUSSION}

\section{Youth Behavior in Watching Televisin Television Ownership}

In order to understand the television watchin behavior, it is necessary to portray the ownership of television of young people in Ciasmara village. In this research, focus on the television watching activities in the search for information and other communications media that are able to be accessed by young people in Ciasmara village. Television is no longer categorized as luxury tool. Almost all families in the Ciasmara have television. The most fundamental differences in television ownership are television brands, television size, television type, and amount of televisions.

Majority of people in Ciasmara already have television in their house. There are even some families who have more than two televisions. Among the existing televisions, there are several television brands owned by young families in Ciasmara Village, among others: Sharp, Toshiba, Polytron and Samsung. Meanwhile, for the size of the television it is ranging from 14 inches to 32 inches. In addition to the number, brand, and size of television, the fundamental thing that differentiates between families in Ciasmara village is the type of television, there are some families that have LED and LCD televisions but the majority of families in Ciasamara Village are television tubes.

But in Ciasmara there are still some families in the village of Sindang Anyar who refused to use television and communication and information technology. The main reason that is because of religious considerations. As stated by Aula (17), according to him, too much bad information come from television, more oever, his parents is also one of the teachers in a pesantren located not so far from the residence hall which is still applying the rules do not use communication technology and information (Modernity)

People in Ciasmara can access information from the television. Television signal quality is also categorized as good. They only use simple antennas. From interviews with 34 young people, there are some of the most watched favorite television stations, SCTV, RCTI, Trans TV and Global TV. The ladies, mothers, and grandmothers have a tendency to watch soap operas Anak Langit and Dunia Terbalik from 18:00 to 21:00. Meanwhile, for youth they tend to watch television from 21:00 to $02: 00$ and watch television stations Trans TV and Global TV with boxoffice programs.
The finding shows that there is a difference in term of television watching pattern between male and female youth. In terms of sharing together, female youth tend to watch television together with their mother, sister, and grandmother while it is different from their male - youth, they tend to watch alone or with their fathers (if watching the football). Male youth are less interested in watching television with their mothers, grandmothers and siblings because of their tendency to watch soap operas. But there is also youth who watched soap opera anak langit with his with family (about motorcycle community). Meanwhile, in term of time of watching television, the female youth have a tendency to watch television from $18.00-21.00$ while the male - youth watch at 20.00 23.00. The time difference in watching television is due to the different programs being watched, the female - youth tend to watch soap operas while the youth tend to watch box-office events. Differences in watch patterns between male - youth and female youth can be seen in detail in Table 1

Table 1. Youth behavior in watching television

\begin{tabular}{cccc}
\hline Youth & Watching Pattern & $\begin{array}{c}\text { Time of } \\
\text { Watching }\end{array}$ & Programs \\
\hline \multirow{4}{*}{ Male } & Alone, sometimes & $20.00-$ & Bioskop Trans \\
& with father & 23.00 & Movies Global \\
& watching football & & TV \\
& Together with & & Sinetron Dunia \\
Female & Mother, Little & $18.00-$ & Terbalik, Anak \\
& sister and & 21.00 & Langit, Dangdut \\
& grandmother & & Indosiar \\
\hline
\end{tabular}

Male and Female Youth in Watching Television

In the context of television watching activities, from Table 2 it can be obtained that majority of youth $(91.2 \%)$ said they watched television at home.

Table 2. Youth television watching Activities

\begin{tabular}{ccc}
\hline Watching TV & Frequency (n) & Percent (\%) \\
\hline Yes & 31 & 91.2 \\
No & 3 & 8.8 \\
\hline Total & 34 & 100 \\
\hline
\end{tabular}

In general, youth in Ciasmara watch television at night, ranging from 18.00 to 02.00 in the morning. Female - youth tend to watch television from 18:00 to 21:00 or according to the schedule of soap operas on television. According to Bella (17), every night she watches television with her sister, mother, and grandmother. The show that Bella and family watch is Anak Langit on SCTV, while the male - youth behavior in watching television is different from the female youth behavior. Male - youth in Ciasmara Village tend to watch television over 20:00 and they watch boxoffice events on Global TV and Trans TV. As stated by Mulyadi (19) who said that in his house there is only one tv that every night will be confliting with his 
siblings, but if the anak langit started, surely he succumbed because all his younger siblings directly watched soap operas but sometimes Mulyadi did not go to watch soap operas and go from house and when box office in trans tv started he returned.

Besides Mulyadi, there is also Deden (16), male- youth majoring in Bumi Putera who also watch Trans TV. He lives with his father, mother and two siblings. Deden often scramble to watch television with his father it was because Deden was about to watch Cinema Trans TV while his father was going to watch the show Angling Dharma. In this conflict, deden succumbs to his father because his father oftenly angry if not watching Angling Dharma. This condition makes Deden go from his house and choose to watch at a friend's house or hang out with his friends. According to Nugraha [2], in his research on TV watching behavior of young people in the village Cipendawa Cianjur. Young people have a tendency to watch entertainment compared to watching other information shows because they are acknowledged by young people everyday they are filled with exhausting activities so only on arrival at home just want to get entertainment

\section{Youth Watching TV at Night}

Media exposure in this study is defined as how often young people watch television, how long young people watch television, and what programs are often seen by young people. The behavior of television watching activites is very diverse, due to several things, among others: (1) the availability of time to watch television, and (2) the availability of programs that interest youth

Most of youth in Ciasmara watch television everyday, generally they watch television at night for several reasons, namely: (1) The majority of young people in the village work and school in the morning, so only have leisure time at night. Youth in Ciasmara have diverse jobs, many of whom work as satai seller, some work as motor mechanics, some work as factory workers in Leuwiliang. According to the Secretary of Ciasmara Village, there are some schools in Ciasmara, namely MTS Ciasmara, SLTP PGRI Ciasmara, SMA Muhammadiyah, and SMK Bumi Putera. (2) Programs offered for young people mostly start from late afternoon until late at night. TV programs available for young people are generally only started in the late afternoon until late at night which makes young people more likely to watch nighttime television. According to Table 3 , the majority of youth $(67.7 \%)$ watch TV everyday, while 14.7 percent of youth rarely watch television or even hardly to watch television. Meanwhile there are 11.8 percent who watch on certain days, and there are about 8.8 percent of young people who do not watch television at all.

From table 3 can be seen that, majority of youth $(64.7 \%)$ watch television everyday. Isolated from information and entertainment center such as Malls and hangout places makes the mobility of youth in Ciasmara only limited inside village or surrounding villages. This research found that youth access information form their Mobile (Smartphone) and Television.

Table 3. Youth frequency in Watching TV

\begin{tabular}{ccc}
\hline $\begin{array}{c}\text { Watching } \\
\text { Frequency }\end{array}$ & $\begin{array}{c}\text { Frequency } \\
(\mathbf{n})\end{array}$ & $\begin{array}{c}\text { Percent } \\
(\mathbf{\%})\end{array}$ \\
\hline Everyday & 22 & 64.7 \\
Certain Days & 4 & 11.8 \\
Almost Never & 5 & 14.7 \\
Never & 3 & 8.8 \\
\hline Total & $\mathbf{3 4}$ & $\mathbf{1 0 0}$ \\
\hline
\end{tabular}

This situation makes frequency of young people in watching television high, because they don't have alternative entertainment. The existence of smartphones on the one hand is able to become an alternative entertainment but not all young people are able to access, they only activate it at times - of course when having more money from their work or pocket money. This makes television the most logical entertainment source to be accessed by youth in the village of Ciasmara.

\section{Watching Duration}

Watching television is a routine activity performed by youth in search of information. However, the duration of young people in Ciasmara village in watching television can be seen from Table 4.

Table 4. Watching duration in a day

\begin{tabular}{ccc}
\hline $\begin{array}{c}\text { Watching } \\
\text { Duration } \\
\text { (Hour/day) }\end{array}$ & $\begin{array}{c}\text { Frequency } \\
\text { (n) }\end{array}$ & $\begin{array}{c}\text { Percent } \\
\mathbf{( \% )}\end{array}$ \\
\hline 0 & 3 & \\
1 & 6 & 8.9 \\
2 & 7 & 17.6 \\
3 & 10 & 20.6 \\
4 & 4 & 29.4 \\
5 & 3 & 11.8 \\
7 & 1 & 8.8 \\
\hline Total & $\mathbf{3 4}$ & 2.9 \\
\hline
\end{tabular}

From Table 4 it can be seen that more than 76 percent of youth watch television less than 3 hours per day. Only about 24 percent of young people watch television more than 3 hours. The low duration of watching TV is caused by high activity of youth in ciasmara village such as working and schooling. For young people who are no longer in school they have a busy business like being a mechanic they work form 09.00 to 17.00 . There are also youth who worked as cleaner at the motor steam. Meanwhile, Youth who are still in school just finished school at around 14:00, 
after that they continue to gather with friends - friends to hangout around their school or hangout place. Meanwhile, those who attend school in the afternoon, usually in the morning they used to play first with their friends and just go to school around at 13:00 and come home around 18.00.

Other reason why youth limited in watching TV it is because at the micro level (family) there is a "space contestation". The conflict in watching television makes youth limited in watching TV. Youth have to succumb to their mothers, grandmothers, and younger siblings. There are also cases where they have to succumb to their father because of the dominance of the parent against the child. As stated by Mulyadi (19) who said that in his house there is only one tv that every night must be conflict with his siblings, but if the sinetron sctv started, surely he have succumbe because all of his younger siblings watched together, Mulyadi chose to go out from the house and when cinema in trans tv began he returned.

\section{CONCLUSION}

1. The favorite TV station to watch are: SCTV, RCTI, Trans TV and Global TV. Female - Youth usually watch TV from 18.00 to 21.00, Male Youth from 21.00 to 02.00 .

2. Television watching - conflict between family members cannot be avoided, especially in prime time, because all parties of family watch TV.

\section{Recomendations}

1. Local government should provide space for youth to gather around because they don't have space in their house.

2. Village youth community should design a program to ensure that rural youth doesn't go form rural area.

\section{REFERENCES}

[1] Tubbs, L. Stewart dan Sylvia, Moss. 1996, Human Communication : Prinsip-Prinsip Dasar. Pengantar: Deddy Mulyana, Bandung : Remaja Rosdakarya.

[2] Nugraha, YA. 2012. Hubungan Orangtua, Televisi, dan Media Masa terhadap Pembentukan Sikap Pemuda terhadap Nilai Pekerjaan Pertanian. [Tesis]. Institut Pertanian Bogor Pelajar.

[3] Nugraha YA, Herawati, R. 2015. Menguak Realitas Orang Muda Sektor Pertanian di Pedesaan. Jurnal Analisis Sosial: Vol 19 No 1. Akatiga: Bandung

[4] Valdiani D, Nugraha YA, Siregar MRA. 2017. Attendance of Mass media and Parents in Defining The Value of Agriculture in The Eyes of Rural (Case Study of Rural Youth at
Horticulture Center in Cianjur Regency). Journal of Humanities and Social Studies Vol 1 No 1. Universitas Pakuan.

[5] Jayawinangun R, Nugraha YA. 2018. Penggunaan Internet dan Media Sosial Orang Muda di Pedesaan (Studi Kasus Orang Muda di Desa Ciasmara Kecamatan Pamijahan). Jurnal Bahasa, Sastra, dan Budaya Wahana. Vol 24 No 2.Universitas Pakuan. (https://journal.unpak.ac .id/index.php/wahana/article/view/946)

[6] Nugraha YA, Siregar MRA. 2018. The Role of Local Loan Institution in Providing Safety Net in Rural Area. Journal of Humanities and Social Studies Vol 2 No 1. Universitas Pakuan.

[7] Nugroho, DR. 2018. Membangun Model Komunikasi Program Tanggungjawab Sosial Perusahaan Untuk Keberdayaan Masyarakat Sekitar (Studi Kasus Desa Lulut, Kabupaten Bogor). Jurnal Sosiohumaniora Vol 20 No 1. Universitas Padjajaran.

[8] Puspitawati, H. 2006. Pengaruh Faktor Keluarga, Lingkungan Teman, dan Sekolah terhadap Kenakalan Pelajar di Sekolah Lanjutan Tingkat Atas di Kota Bogor. [disertasi]. Bogor: Sekolah Pascasarjana, Institut. Pertanian Bogor. Bogor.

[9] S. Setiarani and Y. Suchyadi, "Pola Asuh Orang Tua Terhadap Anak Tuna Netra Berprestasi," J. Pendidik. Pengajaran Guru Sekol. Dasar, vol. 01, no. 01, pp. 15-18, 2018.

[10] Narwoko, J. Dwi \& Suyanto, Bagong,. 2004. Sosiologi Teks Pengantar dan Terapan. Jakarta: Kencana Media Group

[11] Singarimbun, Masri dan Sofian Effendi, Metode Penelitian Survei, Jakarta: LP3ES, 2008

[12] Sugiyono. 2008. MetodePenelitian Kuantitatif Kualitatif dan R\&D. Bandung : Alfabeta 